\title{
INFLUENCE OF TEMPERATURE AND PH LEVEL ON MYCELIAL GROWTH IN LIQUID CULTURES OF CORDYCEPS MILITARIS MUSHROOM MYCELIUM
}

\author{
Melinda Rózsa ${ }^{1, *}$, Maria Apahidean ${ }^{1}$ \\ ${ }^{1}$ University of Agricultural Sciences and Veterinary Medicine Cluj-Napoca, Romania
}

Current Trends in

Natural Sciences

\begin{abstract}
Cordyceps militaris is an entomopathogenic fungus, belongs to the Ascomycetes class and has important pharmacological principles, the most important are polysaccharides and mannitol. Given that in most cases, mushrooms are grown on different substrates of solid consistency, and most supplements containing mycelium from the Cordyceps militaris mushroom are obtained by drying and shredding the mycelium, which has been grown on a solid substrate consisting of brown rice flour or other cereals, so that they very often contain more starch than active ingredients. In this paper we looked at the influence of temperature and $\mathrm{pH}$ level on the growth of the mycelium of this mushroom in liquid culture media. The development of liquid mycelium cultures was tested at temperatures between 20 $30{ }^{\circ} \mathrm{C}$ and at a pH level between 5-7. The highest amount of mycelium was obtained from samples raised at $26{ }^{\circ} \mathrm{C}$ and a pH level of 5.5 .
\end{abstract}

Keywords: Cordyceps militaris, medicinal mushroom, pH, temperature.

\section{INTRODUCTION}

Medicinal mushrooms are a valuable source of biologically active principles such as polysaccharides, ergosterol, cordycepin and mannitol, which are used in traditional and modern medicine (Go et al., 2007).

The Cordyceps militaris mushroom has been used in folk medicine in East Asia since antiquity, being used as a food with tonic and invigorating properties (Mizuno, 1999), in subtropical and temperate regions (Nag and Wang, 2005).

The main bioactive component of medicinal interest of the Cordyceps militaris mushroom is represented by cordycepin (Cunningham et al., 1995), and the therapeutic and medicinal properties are represented by: anticancer activity (Shonkor et al., 2010), antioxidant activity (Wu et al., 2011), antiviral activity (Yuko et al., 2007), anti-fungal activity (Byung et al., 2009), antibacterial activity (Young et al., 2000), immunomodulatory agent for the treatment of immunological diseases (Shin et al., 2009; Rozsa et al., 2016 a).

Collecting Cordiceps militaris mushrooms grown in natural conditions is very expensive, and their cordycepin content is much lower than the content of artificially grown mycelial biomass (Guo et al., 1998; Rozsa et al., 2016 b). 


\section{Current Trends in Natural Sciences}

Vol. 9, Issue 18, pp. 42-46, 2020

https://doi.org/10.47068/ctns.2020.v9i18.006

In recent years, various methods for the production of fungal biomass have been developed and perfected, both on solid substrate (Rozsa et al., $2016 \mathrm{c}, \mathrm{d}$, e) and on liquid surface cultures (Masuda et al., 2007) or submerged cultures (Mao et al., 2005).

The amount of cordycepin and active principles contained in the fungal biomass vary depending on the strain used (Guo et al., 1998; Rozsa et al., 2016 c), the pH of the culture media (Rozsa et al., $2017 \mathrm{a}, \mathrm{b}$ ), the incubation and drying temperatures of mycelial biomass (Rozsa et al., $2017 \mathrm{c}, \mathrm{d}$ ) as well as its chemical composition (Rozsa et al., 2019).

Given all these considerations, in this study were compared two very important factors in a mycelial biomass crop, namely the influence of temperature and $\mathrm{pH}$ of the culture medium on the amount of mycelial biomass obtained, following the values that increase production.

\section{MATERIALS AND METHODS}

The pure culture of Cordyceps militaris from which it started, was maintained in refrigeration conditions at a temperature of $4{ }^{\circ} \mathrm{C}$, this being used as a material for inoculation.

The liquid culture medium was prepared according to the following recipe: for 1 litre of sterilized distilled water, we used $5 \mathrm{~g}$ of ammonium sulphate, $5 \mathrm{~g}$ of magnesium sulphate, $5 \mathrm{~g}$ of potassium phosphate, $15 \mathrm{~g}$ of peptone and $15 \mathrm{~g}$ of yeast.

The $\mathrm{pH}$ of the culture media was acidified with citric acid or basified with sodium hydroxide, so that 5 experimental variants were performed for the following $\mathrm{pH}$ values: 5, 5.5, 6, 6.5 and 7 .

The media thus obtained were incubated at temperatures of $20,22,24,26,28$ and $30{ }^{\circ} \mathrm{C}$.

After incubation, the liquid cultures were centrifuged and the obtained mycelial biomass was washed with distilled water and then dried in an oven at $105^{\circ} \mathrm{C}$ until a constant mass was obtained. The mycelial biomass thus obtained was used for later chemical determinations.

\section{RESULTS AND DISCUSSIONS}

Following the unilateral influence of the incubation temperature on the obtained amount of mycelial biomass, it can be stated that the highest amount of mycelial biomass was obtained in the $24-28{ }^{\circ} \mathrm{C}$ temperature range. Table 1.

Table 1. The unilateral influence of the incubation temperature on the obtained amount of mycelial biomass

\begin{tabular}{|c|c|c|c|c|}
\hline \multirow[b]{2}{*}{ Incubation temperature } & \multicolumn{2}{|c|}{ Mycelial biomass } & \multirow{2}{*}{$\begin{array}{c}\text { Difference } \\
\quad \pm D\end{array}$} & \multirow{2}{*}{$\begin{array}{l}\text { Signification } \\
\text { of difference }\end{array}$} \\
\hline & $\begin{array}{l}\text { g/100 ml } \\
\text { liquid } \\
\text { culture }\end{array}$ & $\%$ & & \\
\hline T0 - mean of experience & 25.97 & 100.0 & 0.00 & Control \\
\hline $\mathrm{T} 1-20^{\circ} \mathrm{C}$ & 20.20 & 77.8 & -5.77 & 000 \\
\hline $\mathrm{T} 2-22^{\circ} \mathrm{C}$ & 22.83 & 87.9 & -3.14 & 00 \\
\hline $\mathrm{T} 3-24^{\circ} \mathrm{C}$ & 27.15 & 104.6 & 1.18 & $* *$ \\
\hline $\mathrm{T} 4-26^{\circ} \mathrm{C}$ & 34.17 & 131.6 & 8.20 & $* * *$ \\
\hline $\mathrm{T} 5-28^{\circ} \mathrm{C}$ & 28.87 & 111.2 & 2.90 & $* *$ \\
\hline $\mathrm{T} 6-30^{\circ} \mathrm{C}$ & 22.60 & 87.0 & -3.37 & 00 \\
\hline LSD (p $5 \%$ ) & & & 0.17 & \\
\hline LSD (p $1 \%)$ & & & 0.24 & \\
\hline LSD (p 0.1\%) & & & 0.34 & \\
\hline
\end{tabular}

Several authors mention the temperature of $24{ }^{\circ} \mathrm{C}$ as optimal for incubating and growing the mycelium of the Cordyceps militaris mushroom (Mao et al., 2005; Patel et al., 2013), and others (Guo et al., 1998; Masuda et al., 2007) mention temperature of $28^{\circ} \mathrm{C}$. 


\section{Current Trends in Natural Sciences}

Vol. 9, Issue 18, pp. 42-46, 2020

https://doi.org/10.47068/ctns.2020.v9i18.006

Current Trends in Natural Sciences (on-line)

ISSN: 2284-953X

Current Trends in Natural Sciences (CD-Rom)

ISSN: 2284-9521

ISSN-L: 2284-952 ISSN-L: 2284-9521

In the case of the strain used by us, the highest amount of mycelial biomass was obtained at the temperature of $26^{\circ} \mathrm{C}$. This temperature was mentioned by Shonkor et al., 2010.

Following the unilateral influence of $\mathrm{pH}$ on the obtained amount of mycelial biomass, it can be stated that at the $5.5 \mathrm{pH}$ level, the highest amount of mycelial biomass was obtained, the obtained results being statistically ensured by very distinctly significant positive differences. (Table 2).

Table 2. Unilateral influence of pH on the obtained amount of mycelial biomass

\begin{tabular}{|c|c|c|c|c|}
\hline \multirow{2}{*}{ Broth pH value } & \multicolumn{2}{|c|}{ Mycelial biomass } & \multirow{2}{*}{$\begin{array}{c}\text { Difference } \\
\quad \pm \mathrm{D}\end{array}$} & \multirow{2}{*}{$\begin{array}{l}\text { Signification of } \\
\text { difference }\end{array}$} \\
\hline & $\begin{array}{c}\mathrm{g} / 100 \mathrm{ml} \text { liquid } \\
\text { culture }\end{array}$ & $\%$ & & \\
\hline P0 - mean of experience & 25.97 & 100.0 & 0.00 & Control \\
\hline P1- 5 & 28.67 & 110.4 & 2.70 & $* *$ \\
\hline $\mathrm{P} 2-5.5$ & 28.37 & 109.2 & 2.40 & $* * *$ \\
\hline P3 - 6 & 26.40 & 101.7 & 0.43 & $* *$ \\
\hline $\mathrm{P} 4-6.5$ & 24.79 & 95.4 & -1.18 & 00 \\
\hline P5 - 7 & 21.63 & 83.3 & -4.35 & 000 \\
\hline $\begin{array}{l}\text { LSD (p } 5 \%) \\
\text { LSD (p } 1 \%) \\
\text { LSD (p } 0.1 \%)\end{array}$ & & & $\begin{array}{l}0.16 \\
0.22 \\
0.28\end{array}$ & \\
\hline
\end{tabular}

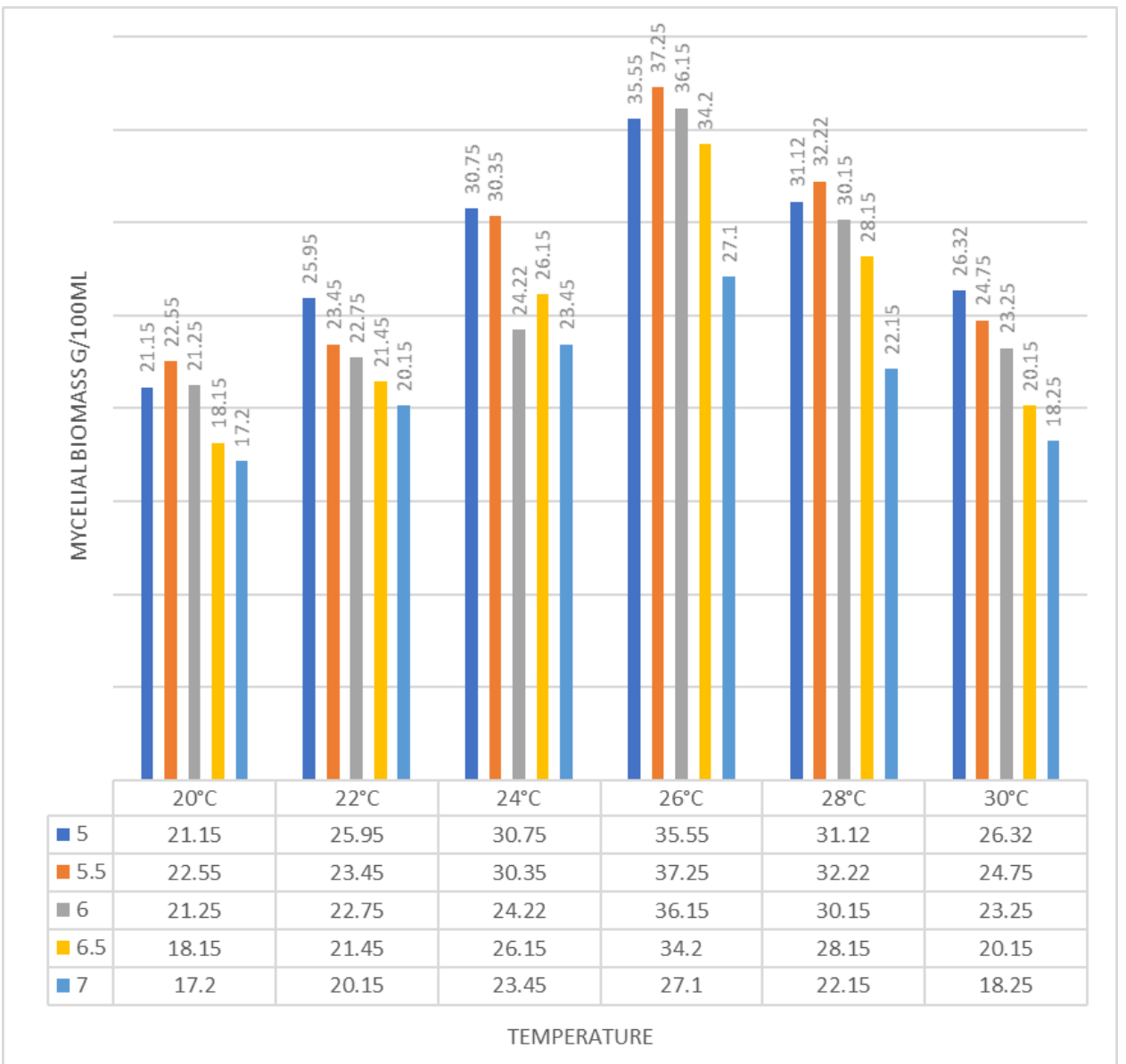

Figure 1. Combined influence of experimental factors, temperature and pH, on Cordyceps militaris mushroom mycelial biomass production 


\section{Current Trends in Natural Sciences}

Vol. 9, Issue 18, pp. 42-46, 2020

https://doi.org/10.47068/ctns.2020.v9i18.006

As in the case of temperature, the $\mathrm{pH}$ level of the culture medium influences the amount of obtained mycelial biomass, so the values we determined are found in the intervals mentioned by other authors (Masuda et al., 2007; Patel et al., 2013).

Following the combined influence of experimental factors, temperature and $\mathrm{pH}$ (Figure 1), in the case of the Cordyceps militaris strain used by us in this study, the highest amount of mycelial biomass was obtained at a temperature of $26^{\circ} \mathrm{C}$ and $5.5 \mathrm{pH}$ value, in this case the cell growth rate was the highest.

Previous studies by Xiao et al., 2004, Kwon et al., 2009, Cheng et al., 2011, also argued that the culture medium at a $\mathrm{pH}$ of 5.5 produces a higher amount of mycelium.

\section{CONCLUSIONS}

In liquid culture media, the acidic $\mathrm{pH}$ is optimal for mycelial biomass, because in the acidic environment the metabolites necessary for the growth and development of the mycelium of Ascomycete fungi are produced faster.

For the used strain of Cordyceps militaris mushrooms, the optimal temperature for the best mycelial biomass production was $26^{\circ} \mathrm{C}$.

\section{REFERENCES}

Byung, T.P., Kwang, H.N., Eui, C.J., Jae, W.P. Ha, H.K. (2009). Antifungal and Anticancer Activities of a Protein from the Mushroom Cordyceps militaris. Vol. 13, 49-54.

Cheng, H., Guo, W., Chang, M., Meng, J., Yang, J. (2011). Study of optimization on liquid fermentation conditions of Cordyceps militaris mycelium. Journal of Shanxi Agricultural University, 31(1), 66-72.

Cunningham, K.G., Hutchinson, S.A., Manson, W., Spring, F.S. (1995). Cordycepin, a metabolic product from cultures of Cordyceps militaris (Linn.) Link. Part I. Isolation and characterisation, J ChemSoc, 2299-2300.

Go, Y.X., Want, Z.S., Li, S.X., Yuan, Q.S. (2007). Effects of multiple factors on accumulation of nucleosides and bases in Corydyceps militaris. Food Chem 102, 1304-1309.

Guo, C., Zhu, J., Zhang, C., Zhang, L. (1998). Determination of adenosine and 3'- deoxyadenosine in Cordyceps militaris (L.) link by HPLC. Zhongguo Zhong Yao Za Zhi 23, 236-237.

Kwon, J.S., Lee, J.S., Shin, W.C. (2009). Optimization of culture conditions and medium components for the production of mycelial biomass and exo-polysaccharides with Cordyceps militaris in liquid culture. Biotechnology and Bioprocess Engineering, 14(6), 756-762.

Mao, X.B., Eksriwong, T., Chauvatcharin, S., Zhong, J.J. (2005). Optimization of carbon source and C:N ratio for cordycepin production by submerged cultivation of medicinal mushroom Cordyceps militaris. Process Biochem. 40, 1667-1672.

Masuda, M., Urabe, E., Honda, H., Sakurai, A. Sakakibara, M. (2007). Enhanced production of cordycepin by surface culture using the medicinal mushroom Cordyceps militaris. Enzyme Microb. Tech. 40, 1199-1205.

Mizuno, T. (1999). Medicinal Effects and Utilization of Cordyceps (Fr.) Link (Ascomycetes) and Isaria Fr. (Mitosporic Fungi) Chineese Caterpiller Fungi, ”Tochukaso" (Review). Intl J Med Mushroom, 1, 251-261.

Nag, T.B., Wang, H.X. (2005). Pharmacological actions of Cordyceps, a prized folk medicine. J Pharm Pharmacol, 57, 1509- 1519.

Patel, K.J., Ingalhalli, R.S. (2013). Cordyceps militaris (L.: Fr.) Link - An Important Medicinal Mushroom. Journal of Pharmacognosy and Phytochemistry, 8192, 315-319.

Rózsa, S., Măniuțiu, D.N., Lazăr, V., Gocan, T.M., Butuza-Bumb, S.F. (2016 a). The influence of culture technology on production and chemical content in Agaricus blazei Murrill mushrooms, Scientific works - Agronomy series, USAMV Iași, vol. 59(2), 237-242, http://www.uaiasi.ro/revagrois/PDF/2016-2/paper/2016-59(2) 46-en.pdf

Rózsa, S., Măniuţiu, D.N., Sima, R., Gocan, T.M., Butuza-Bumb, S.F. (2016 b). Research on the transfer material to obtain mycelium on granular support at the Agaricus blazei Murrill mushrooms, Scientific works - Agronomy series, USAMV Iași, vol. 59(2), 231-236, http://www.uaiasi.ro/revagrois/PDF/2016-2/paper/2016-59(2)_45$\underline{\text { en.pdf }}$ 


\section{Current Trends in Natural Sciences}

Vol. 9, Issue 18, pp. 42-46, 2020

https://doi.org/10.47068/ctns.2020.v9i18.006

Current Trends in Natural Sciences (on-line)

ISSN: 2284-953X

Current Trends in Natural Sciences (CD-Rom)

ISSN: 2284-9521

ISSN-L: 2284-9521

ISSN-L: 2284-9521

Rózsa, S., Măniuțiu, D.N., Lazăr, V., Gocan, T.M., Andreica, I. (2016 c). The influence of pH and the source of nitrogen on the mycelial growth of the Pleurotus ostreatus mushrooms, Scientific works - Agronomy series, USAMV Iaşi, vol. 59(2), 243-246, http://www.uaiasi.ro/revagrois/PDF/2016-2/paper/2016-59(2)_47-en.pdf

Rózsa, S., Măniuțiu, D.N., Gocan, T.M., David, S., Butuza-Bumb, S.F. (2016 d). Research on the influence of temperature on the growth of Agaricus blazei Murrill mushroom mycelium, Agriculture - Science and Practice Journal, Vol 97-98, No 1-2, 53-57, https://journals.usamvcluj.ro/index.php/ agricultura/article/view/12136

Rózsa, S., Măniutiu, D.N., Gocan, T.M., David, S., Butuza-Bumb, F.S. (2016 e). Dynamic of the Agaricus blazei Murrill mushroom mycelium growth, Journal of Horticulture, Forestry and Biotechnology, Volume 20(1), 120122, https://www.journal-hfb.usab-tm.ro/romana/2016/Lucrari\%20PDF/ Vol\%2020(1)\%20PDF/19 Rozsa\% 20D.\%20_Refacuta_BUN.pdf

Rózsa, S., Măniuţiu, D.M., Gocan, T.M., Sima, R., Andreica, I., Rózsa, M. (2017 a). Mycelial biomass production of the Sun mushroom (Agaricus blazei Murrill), Current Trends in Natural Sciences, 6(12), 126-130, https://www.natsci.upit.ro/media/1596/paper-19.pdf

Rózsa, S., Măniuţiu, D.N., Gocan, T. M., Sima, R., Lazăr, V., Rózsa, M. (2017b). Influence of temperature and relative humidity on the studded Agaricus blazei Murrill mushroom compost, Current Trends in Natural Sciences, 6(12), 111-118, https://www.natsci.upit.ro/media/1594/paper-17.pdf

Rózsa, S., Gocan, T.M., Lazăr, V., Andreica, I., Rózsa, M., Măniuțiu, D.N., Sima, R. (2017 c). The Effect of Processing on Chemical Constituents of Agaricus spp. Mushrooms. Notulae Botanicae Horti Agrobotanici Cluj-Napoca, 45(2), 507-516. https://doi.org/10.15835/nbha45210764

Rózsa, S. (2017 d). Correlation between soluble dry matter and $\beta-1,3$ d-glucan content in Agaricus blazei Murrill mushrooms, Lucrări Științifice - Seria Horticultură, USAMV Iași, Volume 60 (2), 131-138, http://www.uaiasi.ro/revista horti-en/arhiva.php?an=2017

Rózsa, S., Măniuțiu, D.N., Poșta, G., Gocan, T.M., Andreica, I., Bogdan, I., Rózsa, M., Lazăr, V. (2019), Influence of the culture substrate on the Agaricus blazei Murrill mushrooms vitamins content, Plants, 8, 316, https://doi.org/10.3390/plants8090316

Shih, I.L., Tsai, K.L., Hsieh, C. (2007). Effects of culture conditions on the mycelial growth and bioactive metabolite production in submerged culture of Cordyceps militaris. Biochemical Engineering Journal, 33(3), $193-201$.

Shin, S., Lee, S., Kwon, J., Moon, S., Lee, S., Lee, C.K., Cho, K., Ha, J.N., Kim, K. (2009). Cordycepin Suppresses Expression of Diabetes Regulating Genes by Inhibition of Lipopolysaccharide-induced Inflammation in Macrophages. DOI 10.4110/in.2009.9.3.98

Shonkor, K., Fujihara, S., Masuda, M., Sakurai, A. (2010). Efficient Production of Anticancer Agent Cordycepin by Repeated Batch Culture of Cordyceps militaris Mutant. October 20-22, San Francisco, USA

Wu, F., Hui, Y., Xiaoning, M., Junqing, J., Zhang, G., Guo, X., Gui, Z. (2011). Structural characterization and antioxidant activity of purified polysaccharide from cultured Cordyceps militaris. African Journal of Microbiology Research Vol. 5(18), pp. 2743-2751.

Xiao, J.H., Chen, D.X., Liu, J.W., Wan, W.H., Fang, N., Xiao, Y., Qi, Y., Liang, Z.Q. (2004). Optimization of submerged culture requirements for the production of mycelial growth and exopolysaccharide by Cordyceps jiangxiensis JXPJ 0109. Journal of Applied Microbiology, 96(5), 1105-1116.

Young, A., Park, S.J., Lee, S.G., Shin, S.C., Choi, D.H. (2000). Cordycepin: Selective Growth Inhibitor Derived from Liquid Culture of Cordyceps militaris against Clostridium spp. J. Agric. Food Chem. 48, 2744-2748.

Yuko, O., Lee, J.B., Hayashi, K., Fujita, A., Park, D.K., Hayashi, T. (2007). In Vivo Anti-influenza Virus Activity of an Immunomodulatory Acidic Polysaccharide Isolated from Cordyceps militaris Grown on Germinated Soybeans. J. Agric. Food Chem. 55, 10194-10199. 